\title{
Swartwattelbome: seën of vloek vir Suid- Afrika?
}

\section{FH SMITH}

Departement Publieke Administrasie \& Bestuur, Universiteit van Suid-Afrika, Posbus

392, UNISA, 0003, smithfh@unisa.ac.za

\section{UITTREKSEL}

Daar is reeds baie geskryf oor uitheemse indringerplante, veral Acacia mearnsii De Wild, die swartwattelboom en die skade wat hierdie plante aan die plaaslike ekologie aanrig. In hierdie artikel word aandag gegee aan die ontstaan van die probleem, asook aan die inbring en verspreiding van swartwattelbome in die Republiek van Suid-Afrika (Suid-Afrika). Die probleme wat deur die onbeheerde verspreiding van wattelbome veroorsaak is, het die regering verplig om op te tree ten einde hierdie probleme te bekamp. Voor 1936 was daar aanvanklik geen formele beleid met betrekking tot die invoer, kweek en beheer van hierdie bome nie. Dit het daartoe gelei dat die regering in die wattelbedryf ingegryp het om ' $n$ sekere mate van beheer te vestig en om probleme met betrekking tot uitheemse indringerplante in die algemeen - en die swartwattelboom in die besonder - die hoof te bied. Voorts sal daar ook gelet word op die rol van swartwattel in volhoubare ontwikkeling deur te fokus op die omgewings-lekologiese probleem van impak op die biodiversiteit en die waterbronne en ook op die voordele wat dit het om woudherstel aan te help. Die artikel bespreek sosiale voordele wat die boom het vir inwoners van landelike gebiede as voorsiener in bou- en konstruksiemateriaal en vuurmaakhout, wat andersins uit die boomveld en/of inheemse woude verkry moet word. Die boom voorsien ook in die houtbehoeftes van die industrie in die vorm van byvoorbeeld pale, pulp en ekstrak. Laastens volg 'n bespreking van die Werk-virWater-program.

\begin{abstract}
Black wattle trees: blessing or curse to South Africa

Much has been written about alien invasive plants, especially Acacia mearnsii De Wild, the black wattle tree and the damage done by these plants to the local ecology. In this article cognisance is taken of how the problem was created, the introduction into and the distribution of black wattle trees in the Republic of South Africa (South Africa). Problems experienced by the uncontrolled spreading of wattle trees forced the government to act, as there was no formal policy before 1936 on the importation, cultivation and control thereof. This led to intervention by government in the wattle industry to establish some form of control and to address the problems related to alien invasive plants in general, and the black wattle tree in particular. Furthermore, cognisance will be taken of the role the black wattle plays in sustainable development by considering the environmental/ecological problem of its impact on bio-diversity and the water sources as well as the advantages it has in the process of forest recovery. Secondly notice will be taken of the social advantages the tree has for the inhabitants of rural areas as a provider of building and construction material and firewood, which would otherwise come from the woodlands and/or indigenous forests. The tree also provides in the timber requirements of industry in the form of for instance poles, pulp and extract. Lastly, the article explores the Work-for-Water Programme.
\end{abstract}

\section{INLEIDING}

In hierdie artikel word die invoer, verspreiding en gebruik van Acacia mearnsii De Wild, die swartwattelboom in die Republiek van Suid-Afrika (Suid-Afrika) beskou. Voor 1936 was daar geen formele beleid oor die invoer, kweek en beheer van hierdie bome nie, en dit het uiteindelik gelei tot probleme wat so ernstig was dat die regering moes optree. Hierdie probleme word later in die artikel beskryf. Daar word voorts gekyk na die oorsprong van die swartwattel en na gebiede waar kommersiële bosaanplanting plaasvind. Dit is belangrik om kennis te neem van die 
belang van die wattelbedryf in Suid-Afrika. Die artikel kyk na faktore soos regeringsintervensie om die wattelbedryf te reguleer, die beskrywing van inheemse indringerplante en die redes waarom die swartwattel in terme van Wet 43 van 1988 as 'n kategorie 2 indringer verklaar is. Daar sal ook gekyk word na die belang van die Werk-vir-Water-program (WVW-program), na beperkings wat op die kweek van uitheemse indringerplante geplaas word, die koste van die WVW-program en kritiek teen hierdie program. Daar word ook kennis geneem van navorsing oor uitheemse indringerplante en aandag word gegee aan enkele van die prominente instellings wat navorsing oor die swartwattelboom doen, asook aan regeringsbefondsing van sodanige navorsing.

\section{OORSPRONG, INVOER EN VERSPREIDING VAN DIE SWARTWATTEL}

In hierdie afdeling word aandag gegee aan die oorsprong van swartwattels, die invoer van hierdie bome in Suid-Afrika, kommersiële bosaanplanting en die sosio-ekonomiese belang van die wattelbedryf.

\subsection{Die invoer van swartwattels}

Daar bestaan botsende verslae oor hoe veral die swartwattel na Suid-Afrika ingevoer is. Daar is verskeie spesies ingebring, naamlik Acacia saligna (Labill.) H.L. Wendl., algemeen bekend as die Port Jackson-boom. ${ }^{1}$ Hierdie boom is hoofsaaklik op die sandduine in die Wes-Kaap geplant om te verhinder dat die los duinsand van die kusgebiede wegwaai. In die verlede is die bas in die leerlooierybedryf gebruik, terwyl die hout goeie vuurmaakhout uitgemaak het, al het dit nie geskikte afmetings bereik om as houtvesel gebruik te word nie. ${ }^{2}$ Hierdie boom word in sommige publikasies ook die Australiese wattel genoem, en daar is gevind dat dit 'n vinnige groeier tot nadeel van die inheemse plante is, ${ }^{3}$ soos steeds in die Wes-Kaap gesien kan word. Acacia mearnsii De Wild, die swartwattel, is die tweede tipe wattel wat ingebring is. Volgens amptelike dokumentasie is laasgenoemde in 1881 deur Baron F. von Mueller in die Kaapkolonie ingebring toe hy 'n besending saad uit Australië ontvang het. Daar is beweer dat die bas en hout van hierdie boom nuttig in die Kaapkolonie kon wees. ${ }^{4}$ Die huidige naam van hierdie Australiese plant is gebaseer op 'n eksemplaar wat deur Mearns in Kenia versamel is. De Wildeman het in 1925 die plant na Mearns vernoem op grond van sy ontdekking van 'n boom wat wild in Kenia opgekom het, en was nie daarvan bewus dat die swartwattel uit Australië na Kenia gebring is nie. Sedertdien word die naam Acacia mearnsii de Wild en die volksname swartwattel of black wattle in amptelike publikasies gebruik. Ander plaaslike volksname vir die boom is (swart-) basboom, swartwattelboom, blikwortelboom, en in Engels Australian black wattle of bloot wattle. Die naam Acacia mearnsii de Wild en die volksnaam swartwattel word in amptelike publikasies aangetref. ${ }^{5}$ In ander bronne wat die onderstaande bron aanhaal, word vermeld dat die swartwattel baie vroeër reeds ingebring is - daar word algemeen aanvaar dat John van der Plank, 'n boer van Camperdown in KwaZulu-Natal, dit ingevoer het om te dien as bron van skuiling en vuurmaakhout. Aan die ander kant is daar rekords wat aantoon dat die "black wattle" reeds teen 1858 in die Kaapstadse Botaniese Tuin gegroei het. ${ }^{6}$ Daar moet ook gewys word op Acacia decurrens (Wendl.) Wild, algemeen bekend as die groenwattel, aangesien die boom en die swartwattel dikwels met mekaar verwar word. ${ }^{7}$

Die blaam vir die uiteindelike verspreiding van die swartwattel rus op private individue, private instellings en die sentrale regering. In 1912 is $200 \mathrm{lb}$ (sowat $91 \mathrm{~kg}$ ) swartwattelsaad beskikbaar gestel deur die Tabakproefstasie op Piet Retief. ${ }^{8}$ Verder is $1 / 2 \mathrm{lb}$ (sowat $0,23 \mathrm{~kg}$ ) swartwattelsaad aan die Waaikraal Staatskool in die Pretoria-distrik gegee vir die kweek van

Suid-Afrikaanse Tydskrif vir Natuurwetenskap en Tegnologie, Jaargang 25 No 4: Desember 2006 
bome. ${ }^{9}$ Die aanplant van wattelplantasies is ook toegelaat op staatsgrond by Winterton in die Middellande van KwaZulu-Natal en naby die Drakensberge. ${ }^{10}$

\subsection{Kommersiële bosaanplanting}

Soos reeds voorheen genoem, is die wattel aanvanklik in KwaZulu-Natal ingevoer as bron van skuiling en vuurmaakhout, maar teen 1880 is dit hoofsaaklik vir die produksie van bas in kommersiële plantasies gekweek. In 1886 is 'n besending bas die eerste keer na Groot-Brittanje uitgevoer. ${ }^{11}$

In Suid-Afrika is die wattelbedryf tans hoofsaaklik gebaseer op die kweek van die swartwattel (A. mearnsii), wat inheems aan Australië is. Die belangrikste plantasies is geleë in die koel misgordel langs die oostelike platorand tussen hoogtes van $400 \mathrm{~m}$ en $1200 \mathrm{~m}$, waar die jaarlikse reënval hoër as $800 \mathrm{~mm}$ is. ${ }^{12}$ Melding word ook gemaak van staatswattelplantasies in die omgewing van die destydse Pietersburg, Tzaneen en Louis Trichardt ${ }^{13}$ asook in die destydse Suid-Transvaal. ${ }^{14}$

Die swartwattel is ook in die Transkei (tans deel van die Oos-Kaap) deur die staat gekweek. Teen 1898 is berig dat die vinnige bevolkingsgroei meegebring het dat daar 'n steeds toenemende vraag na hutboumateriaal is, en daar is voorgestel dat wattelplantasies gevestig moet word om onder andere in die vraag na pale te voorsien. Hierdie voorstel is aanvaar en plantasies is in baie dele van Transkei gevestig, sodat die staatswattelplantasies teen 1905 'n gebied van 400 hektaar beslaan het. Teen Maart 1975 het die staatswattelplantasies alhier reeds 'n gebied van 2648 hektaar beslaan, terwyl 1587 hektaar in besit was van dorpsbesture. ${ }^{15}$

Teen 1910, toe die Unie van Suid-Afrika tot stand gekom het, was daar 59000 hektaar wattelplantasies in totaal in KwaZulu-Natal en die voormalige Transvaal om bas vir die leerlooierybedryf te produseer. Kommersiële plantasies van uitheemse spesies was 'n gesonde belegging. Die privaat sektor het veral ná die Tweede Wêreldoorlog groot plantasies van onder andere swartwattelbome gevestig. ${ }^{16}$

Aanvanklik het die regering van die Zuid-Afrikaanche Republiek (die voormalige Transvaal) nie betrokke geraak by bosaanplantingsprojekte nie, maar dit aan die privaat sektor oorgelaat. Die regering het wel uitheemse saailinge teen 'n nominale prys voorsien en 'n voorligtingsdiens bedryf wat inligting verskaf het oor die vestiging van uitheemse plantasies. ${ }^{17}$ Die ontdekking van goud was die stukrag agter die aanplanting van uitheemse boomspesies soos die swartwattel deur privaat myneienaars. Dit moes dien as bron van mynstutte en om die mure van die myntonnels te versterk. Die inheemse woude kon nie 'n genoegsame volume houtvesel vir hierdie doeleindes oplewer nie. ${ }^{18}$

Die totale oppervlak van kommersieel gekweekte wattelplantasies was in 1990131679 hektaar, geleë in 'n gordel van suidoostelike Mpumalanga, deur die noorde van KwaZulu-Natal en die Middellande tot in die suide van KwaZulu-Natal, ${ }^{19}$ asook (soos hierbo verduidelik) die voormalige Transkei. Die wattelbasbedryf is aanvanklik in KwaZulu-Natal ontwikkel, wat $69 \%$ van die totale oppervlak van 124000 hektaar basbome in 1990 in Suid-Afrika gehuisves het. Die voormalige Transvaal, hoofsaaklik die huidige Mpumalanga, is die ander hoofprodusent met $30 \%$ van die totale oppervlak onder basboomaanplantings. ${ }^{20}$

Die aanname kan gemaak word dat alle swartwattels wat buite hierdie afgebakende gebiede groei, waar swartwattels kommersieel gekweek word, uitheemse indringerplante is. In die meeste lande waar dit aangeplant is, het die boom buite die kommersiële plantasies versprei en oorbeweide en kaalgebrande gebiede ingeneem. ${ }^{21}$ Daar is waargeneem dat selfs in die gebiede waar die swartwattel gekweek word, groot stroke grond ingeneem word deur bome wat wild opslaan. Daar is skaars 'n distrik waar die boom tans nie onbeheerd groei nie. 


\subsection{Sosio-ekonomiese belang van die wattelbedryf}

Die wattelbedryf is om die volgende redes van sosio-ekonomiese belang.

\subsubsection{Gebruike van swartwattel}

Swartwattelhoutvesel word nie net vir spaanderhout gebruik nie, maar ook vir mynstutte, vuurhoutjies, brandhout, houtskool, veselbord, papier, rayonpulp en parketvloere. Lym en vernis word van die hars vervaardig. ${ }^{22}$

\subsubsection{Bedrywe}

Die wattelbedryf is 'n vennootskap tussen die kwekers, wat verteenwoordig word deur die SuidAfrikaanse Wattelkwekersvereniging (SAWKV) en die prosesseerders. Die meeste kwekers is ook lede van die koöperasies wat verantwoordelik is vir die prosessering van wattelbas. Die bemarking van die produkte wat van wattelbas gemaak word, word gesamentlik deur die kwekers en die vervaardigers gedoen deur middel van die Wattelbasbedryf-bemarkingskomitee. Altesaam $96 \%$ van die produkte van die prosesseringsfabrieke word uitgevoer. ${ }^{23}$

\subsubsection{Sosio-ekonomiese impakte}

Die kommersiële swartwattels word deur sowat 2700 boere, waarvan die meerderheid swart kleinboere is, gekweek. Sowat $75 \%$ van alle geregistreerde wattelkwekers val in hierdie kategorie. Die uitbreiding van wattelverbouing onder hierdie groep maak voorsiening vir 'n groeiende getal entrepreneurs met 'n verskeidenheid sakegeleenthede. Die bome word gekweek ooreenkomstig 'n tienjaarsiklus en word bestuur om te verseker dat die kwekers 'n gereelde inkomste uit hul bome ontvang en dat 'n gereelde voorraad goeie wattelbas vir prosessering by die onttrekkingsfabrieke beskikbaar is. Nie slegs die bas nie maar ook die houtvesel is sterk in aanvraag. Vir elke ton bas wat geoes word, produseer die swartwattels ook 5 ton beskikbare houtvesel. Sodra die bas en houtvesel van die terrein verwyder is, word die volgende aanplanting gedoen. Navorsing het getoon dat die swartwattel herhaaldelik op dieselfde terrein geplant kan word sonder dat die opbrengs benadeel word. Aangesien dit 'n peulgewas is, plaas die plant stikstof in die grond, wat tot die boer se voordeel gebruik kan word indien hy besluit om 'n kontantgewas soos mielies aan te plant voordat hy weer bome plant. ${ }^{24}$

Natuurbewaring is ook vir hierdie bedryf 'n prioriteit. Natuurlike hulpbronne word gewoonlik goed beskerm op wattelplantasies. Kontoeraanplanting, die opstapeling van takke tussen die ou boomrye, asook grasbeplante waterweë om oortollige water ná hewige reënstorms weg te voer, is enkele van die metodes wat gebruik word om afvloei te hanteer en die grond teen erosie te beskerm. Wanneer aanplantings gedoen word, word sorg gedra dat die bome nie inbreuk maak op waterloop of vleilande nie. Dit word gedoen om te verseker dat die stroomvloei nie benadeel word nie en dat ander watergebruikers stroomaf ook hulle regmatige deel van die waterbronne kry. Waar wattel en ander uitheemse plante wel inbreuk maak op hierdie oewergebied, word hulle verwyder. ${ }^{25}$

Swartwattels het ook bygedra tot natuurbewaring en die beskerming van inheemse woude. Die groeiperiode van swartwattels is tussen ses en agt jaar. Anders as die stompe van die groenwattel (A. decurrens ) wat in die grond gelaat word nadat die bome geoes is, loop die stompe van die swartwattel nie weer uit nie. ${ }^{26}$ Hierdie is 'n aspek wat ingedagte gehou moet word wanneer die twee soorte wattels verwyder word. Dit is belangrik, aangesien aanvaar kan

Suid-Afrikaanse Tydskrif vir Natuurwetenskap en Tegnologie, Jaargang 25 No 4: Desember 2006 


\section{0}

word dat die bewoners van die stamgebiede en reservate hul ou hutte elke twee tot drie jaar afbreek en dan jong bome afkap om te gebruik as raamwerke vir nuwe hutte. Deur die wattelplantasies tussen die woongebiede en die jong inheemse woude te plaas, word die moontlikheid geskep dat die wattels benut word pleks van die bome van die woud. ${ }^{27}$ In KwaZulu-Natal het navorsing getoon dat wanneer randgrond bemes word, swartwattels op grond angeplant kan word wat as ongeskik vir die kweek van ander gewasse beskou word. ${ }^{28}$

Oor die jare was dit nodig om die bestuur van hierdie plantasies aan te pas by die veranderende houtveselbehoeftes van die bevolking. Die stygende lewenstandaard het onvermydelik gelei tot 'n verbetering in die struktuur van huise. Hutte wat in die ou styl gebou is, is vervang deur rondawels met mure wat óf van sooie óf van pale met gooipleister gebou was. Die gevolg was dat daar 'n groter mark vir paaldikte boumateriaal en minder vir latte ontstaan het. Deesdae is daar ' $n$ aansienlike toename in die behoefte aan gesaagde bouhoutvesel. ${ }^{29}$ Hopelik lei hierdie situasie tot 'n afname in die vraag na wattelpale en dus in die behoefte om die boom te kweek.

Dit blyk duidelik dat daar sedert die vroegste dae van bosbestuur plantasies van vinnig groeiende hardehout soos Acacia, en meer spesifiek die swartwattel, aangeplant is. Dit was om te voorsien in die bevolking se behoeftes aan brandstof, latte, pale en ander boumateriaal. Daar bestaan geen twyfel dat hierdie plantasies 'n groot rol gespeel het om te voorkom dat die inheemse woude nie totaal uitgeroei word nie. ${ }^{30}$

Uit bogenoemde kry 'n mens die indruk dat die Suid-Afrikaanse wattelbedryf suksesvol en goed georganiseer is. Dit was nie altyd die geval nie. Ingryping deur die regering was beide in die verlede, en is tans steeds nodig.

\section{REGERINGSINTERVENSIE IN DIE WATTELBEDRYF}

Sedert 1936 was dit vir die regering-van-die-dag nodig om in die wattelbedryf in te gryp om dit te reguleer, om die probleem van uitheemse indringerplante die hoof te bied, om die Werk-virWater-program te inisieer en om hulp te verleen met betrekking tot navorsing oor uitheemse indringerplante, veral die swartwattelboom.

\subsection{Regeringsintervensie om die wattelbedryf te reguleer}

Die regering het die volgende stappe gedoen om die wattelbedryf te reguleer.

\subsubsection{Basproduksie}

Geen wattelbas word deur die staat geprosesseer nie. Die omstandighede in die wattel- en wattelbasbedryf het egter so kritiek geraak dat die staat verplig was om in die bedryf se aktiwiteite in te gryp om totale ineenstorting en groter werkloosheid te voorkom. Die bevolking verwag nie net in sulke gevalle van die regering om op te tree nie, maar het dit reeds in die aanhef van die vorige Grondwet van die Republiek van Suid-Afrika, Wet 110 van $1983,{ }^{31}$ so beskryf. Hierin word dit duidelik gestel dat die staat daarvoor verantwoordelik is om die tevredenheid sowel as die geestelike en materiële welvaart van almal te bevorder.

Tot 1936 was daar oor die produksie en bemarking van wattel en wattelprodukte geen regeringsbeheer nie. In daardie jaar het buitelandse mededinging genoodsaak dat maatreëls getref word om die bedryf te stabiliseer en die reorganisasie van die bedryf is in 1937 afgehandel. Van die maatreëls sluit in dat alle plaaslike uitvoerders en hul handelsmerke geregistreer moes word en dat bas wat vir uitvoer bestem was, volgens vasgestelde standaarde gegradeer moes word. ${ }^{32}$ Die Sekretaris van Bosbou het die Sekretaris van die Tesourie skriftelik 
in kennis gestel dat die kabinet op 1958-10-13 die aanstelling van die Kommissie van Ondersoek na die Wattelbedryf goedgekeur het. ${ }^{33}$ Voortvloeiend hieruit is ' $\mathrm{n}$ ad hoc-komitee deur die Minister van Bosbou aangestel om ondersoek in te stel na spesifieke probleme wat die wattelbasbedryf ondervind het. Die komitee moes ook wetgewing aanbeveel om hierdie probleme die hoof te bied. Dit was dwingend noodsaaklik, want in 1959 was daar sowat 161876 hektaar kommersiële wattelplantasies en die uitvoer van wattelbas en wattelekstrak was R10 miljoen aan buitelandse valuta werd. Die wattelbedryf was 'n werkskepper en dit het dus groot waarde vir die Suid-Afrikaanse ekonomie gehad as 'n verdiener van buitelandse valuta. Aanvanklik is daar geen probleme ondervind met betrekking tot die kweek van wattel en die bemarking van wattelbas en -ekstrak nie. Die produksie was voldoende en kon geredelik op wêreldmarkte verkoop word.

In 1958 het die oorproduksie van wattelbas in Suid-Afrika byna gelei het tot 'n ekonomiese ramp in die wattelbedryf. Om die probleem verder te vererger, is plaasvervangers vir leer geproduseer. Dit het tot ' $n$ afname in die vraag na wattelekstrak gelei. 'n Verdere probleem was dat wattelbas van 'n boom wat wild in Suid-Amerika gegroei het (die bron het die betrokke boom nie genoem nie), goedkoper verkoop kon word op die wêreldmarkte as wat die geval was met Suid-Afrikaanse wattelbas. Beheer oor die produksie en prosessering van wattelbas het dus noodsaaklik geword om die plaaslike bedryf teen ineenstorting te beskerm. Sodoende sou die bedryf se ekonomiese kapasiteit herstel word. Die Minister het ook benadruk dat dit die doel van die Wet op die Wattelbasnywerheid, Wet 23 van 1960, ${ }^{34}$ was om owerheidsbeheer uit te oefen oor die produksie van wattelbas en -ekstrak, asook oor die prys wat die prosesseerders aan die produsente betaal het. ${ }^{35}$ Sedertdien is beheer uitgeoefen deur die Wattelbasnywerheidsraad (Raad), wat bestaan het uit 'n gelyke aantal verteenwoordigers van die wattelkwekers en die prosesseerders. Die funksie van die Raad was om uitvoering te gee aan die ooreenkoms tussen die wattelkwekers en die prosesseerders. Hierdie ooreenkoms het voorsiening gemaak vir die prys wat deur die prosesseerders aan die kwekers betaal is, vir ' $\mathrm{n}$ graderingstelsel vir wattelbas, vir die regulering van die produksie van wattelbas en vir die implementering van 'n heffing op wattelbas om die aktiwiteite van die Raad te finansier. ${ }^{36}$

Teen 1962 is die regering deur die Suid-Afrikaanse Wattelkwekersvereniging (SAWKV) versoek om die wattelkwekers by te staan om die grootskaalse insolvensie te bekamp wat gevolg het op oorproduksie en lae pryse. ${ }^{37}$ Die Wysigingswet op die Wattelbasnywerheid, Wet 24 van $1986,{ }^{38}$ is gepromulgeer toe die Suid-Afrikaanse Wattelbasmeulenaars- en Uitvoerdersassosiasie ontbind het nadat die uitvoermarkte vir gekapte en gemaalde wattelbas verdwyn het. Dit het voorsiening gemaak vir die beheer van die bedryf deur die kwekers en vervaardigers van wattelprodukte. ${ }^{39}$

\subsubsection{Prosessering}

Die Raad het veranderinge aan wetgewing voorgestel om voorsiening te maak vir die invoer van wattelbas uit Swaziland. ${ }^{40}$ Wattelbas is vanaf Swaziland na Suid-Afrika ingevoer vir prosessering, 'n gebruik wat uiteindelik verbied is. ${ }^{41}$ Die wattelbedryf het hierin 'n bedreiging vir die plaaslike industrie gesien aangesien dit die wattelkwekers van Swaziland kon verplig om hul eie prosesseringsaanlegte te vestig, wat op sy beurt tot finansiële verliese vir die plaaslike prosesseerders, asook gepaardgaande werksverliese kon lei. Hierdie verbod is uiteindelik herroep, ${ }^{42}$ maar 'n permit was egter nog steeds nodig om wattelbas uit Swaziland in te voer. ${ }^{43}$

Die SAWKV het sedert 1984 voorleggings aan die Departement Landbou en die voorsitter van die Raad gedoen om die verbod op die invoer van wattelbas uit Swaziland sonder 'n permit opgehef te kry. 'n Soortgelyke versoek is deur die voorsitter van die Raad aan die 
Departement Landbou gerig. ${ }^{44}$ Op 1989-05-26 is hierdie verbod geskrap. ${ }^{45}$ Deur hierdie optrede van die regering is die plaaslike prosesseerders nou verseker van 'n konstante voorraad wattelbas, wat gelei het tot die behoud van werksgeleenthede. Die resultaat van hierdie ondersoek na die stand van sake in die wattelbedryf en die beleidsveranderinge met betrekking tot die invoer van wattel uit Swaziland, was dat die Bosboutak van die Departement van Omgewingsake en Bosbou betrokke geraak het by die handel in wattelbas. Dit het gelei tot ' $n$ nuwe doelwit vir die tak, en daarbenewens het een van sy lede voorsitter van die Raad geword. ${ }^{46}$

\subsubsection{Saadproduksie}

Die SAWKV was besorg dat die groothandeluitvoer van swartwattelsaad na ander lande 'n bedreiging kon inhou vir die Suid-Afrikaanse wattelbedryf. Die rede hiervoor is dat die bedryf met behulp van navorsingsinstansies baanbrekerswerk gedoen het in die verbetering van veral die saad van die swartwattel, waardeur siektevrye bome met 'n hoë groeikoers verseker is. Dit was nodig om hierdie bate te beskerm, aangesien daar altyd die gevaar was dat lande wat met Suid-Afrika om die mark in wattelekstrak meeding, sou probeer om van hierdie saad in die hande te kry. Die bedryf het dus die Raad en die Departemente van Landbou en Handel en Nywerheid versoek om 'n totale verbod op die uitvoer van verbeterde plaaslike swartwattelsaad te plaas. ${ }^{47}$ Dit is uiteindelik gedoen. Die verbod is in 1989 ingevoer. ${ }^{48}$

\subsection{Uitheemse indringerplante}

Die swartwattel is amptelik deur wetgewing as 'n kategorie 2 indringer verklaar.

\subsubsection{Die omskrywing van uitheemse indringerplante}

Die sewentiende eeu is gekenmerk deur die beweging van mense om nuwe gebiede te koloniseer. Hierdie koloniste het plante wat aan hulle bekend was na hul nuwe lande saamgeneem en dit daar gevestig. Hierdie plante het uiteindelik 'n toenemende probleem geraak in hul oorgeplante gebiede aangesien daar geen natuurlike vyande of siektes was om hul groeiof vermenigvuldigingskoers in toom te hou nie. 'n Verdere probleem was dat in gebiede waar die klimaat ideaal was, hulle vinnig vermeerder het en in baie gevalle feitlik die gebied ten koste van inheemse plantegroei ingeneem het. ${ }^{49}$

Uitheemse plantspesies kan indringers word wanneer hulle in 'n nuwe gebied of land ingebring word sonder hul natuurlike stel plantvretende insekte en patogene wat hulle in hul natuurlike habitat in bedwang hou. Die gevolg is dat hulle in die nuwe omgewing dikwels in staat is om groot hoeveelhede saad te produseer, om plaaslike plante uit te druk en digte stande te vorm wat vinnig versprei en die landskap verander. Hulle beïnvloed gewoonlik die welsyn van sowel die menslike bewoners as die biodiversiteit van die gebied. ${ }^{50}$

Daar word onderskei tussen verklaarde onkruide (weed) en verklaarde indringers. Onkruid word onder meer beskryf as ' $n$ wilde plant wat op 'n plek groei waar dit nie gewens is nie. ${ }^{51}$ Verklaarde kategorie 2 indringers word slegs toegelaat in afgebakende gebiede onder beheerde toestande. Voorts word die invoer van en handel in plantmateriaal van sodanige plante beperk tot permithouers. Plante wat buite afgebakende gebiede voorkom, moet beheer of uitgeroei word indien moontlik, behalwe in biologies beheerde reservate. Sodanige plante moet ook verwyder word binne 30 meter van die 1:50 jaar vloedlyn van waterbronne of vleilande tensy die nodige magtiging vooraf verkry is. Dié verbod is nie van toepassing op A. mearnsi nie. ${ }^{52}$

Statistiek dui aan dat daar 198 verklaarde onkruide en indringerplante in Suid-Afrika is. Daar is ook voorgestel dat ' $n$ verdere 60 plante as onkruide en indringerplante verklaar word. ${ }^{53}$ 
Indien daar nie beheer is nie, kan die bestaande probleemsituasie binne 15 jaar verdubbel. Indringerplante benadeel die gebiede waar hulle ingevoer word op die volgende maniere:

- Veroorsaak 'n verlies aan biodiversiteit en ekosisteem-veerkragtigheid omdat hulle inheemse flora verdring en sodoende komplekse ekosisteme inperk tot monokulture. Op dié manier word die habitat vir sowel plante as diere vernietig. ${ }^{54}$

- Wanneer uitheemse indringerplante inheemse spesies verdring, gaan die insekte wat van hierdie plante afhanklik is, dood. Dit lei gewoonlik tot 'n verlies aan die voedselvoorrade van insekvretende voëls en klein soogdiere, en hulle sterf ook uit. Die gevolg is dat groter diere wat van hierdie kleiner diere leef, ook doodgaan weens die breuk in die voedselketting. ${ }^{55}$

- Die groter verdamping weens die hoër transpirasiekoers van hierdie ruigtes indringerplante verminder die grondwater en dus die volume water wat die riviere bereik. Dit droog ook vleilande en oewergebiede uit, wat weer die erosie in hierdie areas laat toeneem.

- Veroorsaak verliese aan potensieel produktiewe grond en die verlies van weipotensiaal en veeproduksie.

- $\quad$ Kan tot die vergiftiging van mense en vee aanleiding gee.

- Veroorsaak 'n verhoging in die koste van brandbeskerming en skade weens veldbrande omdat die stande indringerplante nie net digter as natuurlike plantegroei is nie, maar die hout ook meer harsagtig is, wat warmer vure tot gevolg het.

- Verhoog die vlak van erosie ná veldbrande in gebiede waar daar digte indringing is en laat damme toeslik. ${ }^{56}$

- $\quad$ Ook tradisionele genesers word deur die toename in indringerplante geraak, aangesien hulle hul medisynes maak van inheemse kruie wat hoofsaaklik in die woude van Afrika groei. In die mate wat die woude bedreig word, word hul medisyne ook in gevaar gestel. ${ }^{57}$

Swartwattels voldoen aan elkeen van die bogenoemde kenmerke van uitheemse indringerplante en is daarom 'n gevaarlike indringer. Vervolgens moet die verspreiding van swartwattels as indringerplante buite die kommersiële plantasies beheer word.

\subsubsection{Swartwattels as uitheemse indringerplante buite die kommersiële plantasies}

Op die oomblik kom swartwattels wydverspreid in Suid-Afrika voor, veral langs riviere, strome en slote, hoofsaaklik in die grasveld en fynbos soos aangedui in figuur 1. In byvoorbeeld die Wes-Kaap en Oos-Kaap het dit langs die paaie en riviere versprei en kom voor oor 'n gebied van die Sederberge tot in die (voormalige) Transkei. Dit groei baie goed, veral in hoë reënvalgebiede in diep, goed gedreineerde grond, maar sal ook in vlak grond groei indien daar genoeg water is. In baie gebiede waar hierdie bome buite die kommersiële plantasies voorkom, vorm die swartwattel digte, ondeurdringbare boskasies wat die inheemse plantegroei verdring terwyl dit langs strome die watervloei belemmer. Persoonlike waarnemings wat gedurende 2000 langs 'n waterstroom net buite die grense van die Sederberg Wildernisgebied by Clanwilliam gedoen is, het daarop gedui dat die skoonheid van die delikate fynbos- en grasveld-ekosisteme vervang is deur ' $n$ eentonige see van swartwattel. Dit is nou bekend dat die saad van die swartwattel 'n lewensduur van 50 jaar het. Indien 'n mens verder daaraan dink dat die grond onder 'n ou boom tot 20000 sade per vierkante meter kan bevat, dan is dit duidelik dat die potensiële verspreiding van die bome en die gepaardgaande beheerprobleme nie oorskat kan word nie. Dik ruigtes

Suid-Afrikaanse Tydskrif vir Natuurwetenskap en Tegnologie, Jaargang 25 No 4: Desember 2006 
swartwattel is dikwels 'n kenmerk van gebrande gebiede, omdat die vuur die ontkieming van die sade stimuleer. ${ }^{58}$

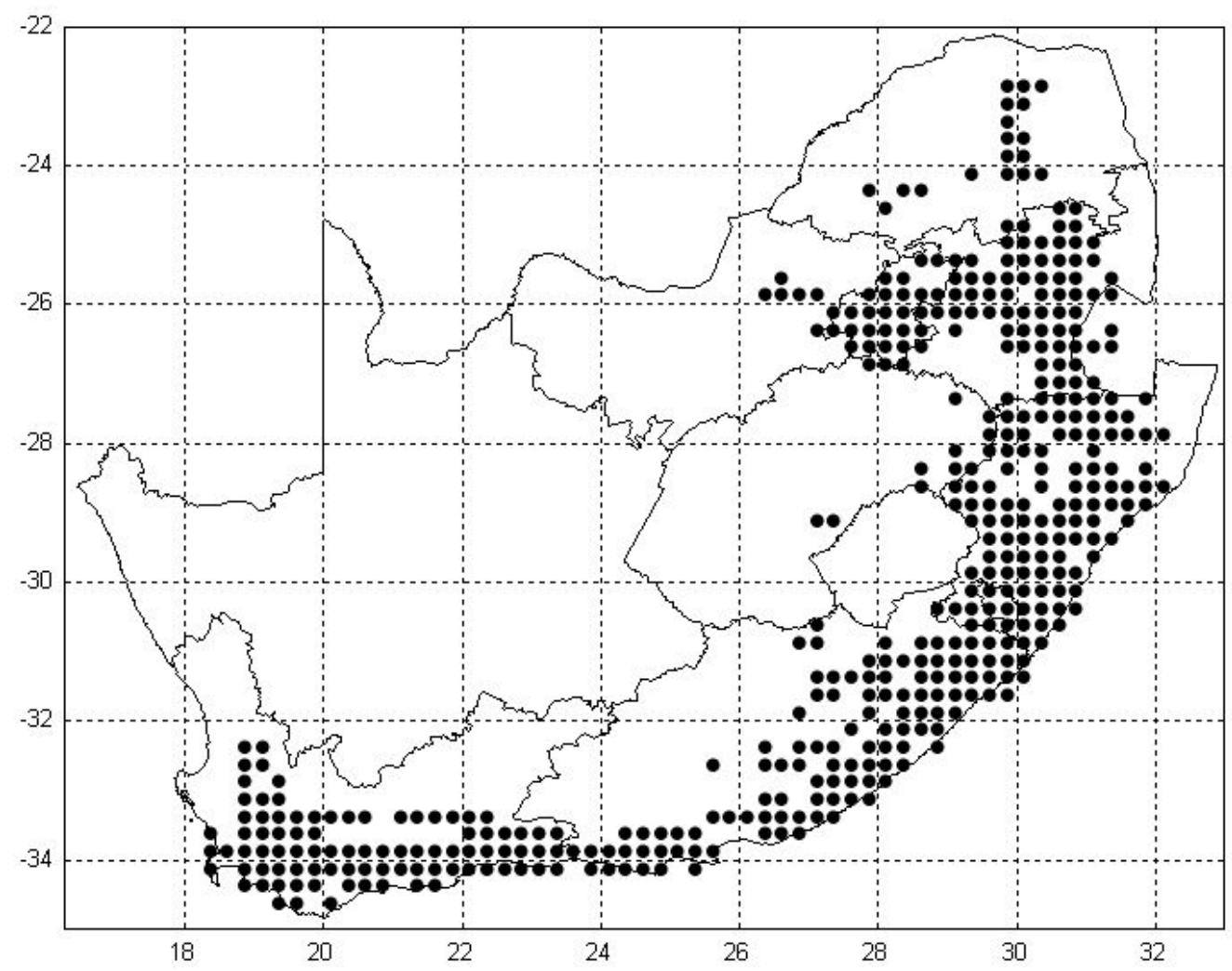

Figuur 1: Verspreiding van swartwattelbome in Suid-Afrika.

BRON: Henderson, L. 2001. Alien weeds and invasive plants: a complete guide to declared weeds and invaders in South Africa including another 36 species invasive in that region. (Pretoria: Plant Protection Research Institute, Agricultural Research Council), p. 222. 
In 'n onlangse raming van die omvang van uitheemse indringerplante in Suid-Afrika is die swartwattel gelys as die indringer wat die wydste in alle dele van Suid-Afrika versprei is. Dit word gesien as 'n sterk negatiewe invloed op stroomvloei asook die watervloei uit stroomgebiede omdat dit so vinnig langs oewersones versprei en geneig is om vinnig digte ruigtes te vorm wat deur' $n$ hoë biomassa en blaararea gekenmerk word. ${ }^{59}$ Daar is meer fondse deur die WVW-program vir die beheer van die swartwattel as vir alle ander indringerplante tesame toegewys. ${ }^{60} \mathrm{Om}$ die probleme te bekamp wat met die indringing van uitheemse bome gepaardgaan, het die regering verskeie indringerplantbeheermaatreëls van stapel gestuur.

\subsection{Indringerplantbeheermaatreëls}

Die Handves van Regte van die Grondwet van Suid-Afrika, Wet 108 van 1996, artikel $24^{61}$ onder die opskrif "Omgewing" lui dat elke persoon onder meer die reg daarop het dat die omgewing beskerm word deur middel van redelike wetgewing en ander maatreëls om ekologiese agteruitgang te verhinder en om ekologies volhoubare ontwikkeling en gebruik van natuurlike hulpbronne te verseker. Die regering het 'n reeks instrumente voorgestel om probleme met betrekking tot grondagteruitgang die hoof te bied. Dit sluit in nuwe wetgewing oor grondregte, pogings om 'n "Grondsorg"-etiek in te stel, wette met betrekking tot ontwikkelingsbeplanning vir landelike gebiede en veranderings aan voorligtingspraktyke soos voorsien in die Groenskrif oor Landbou. Die werklikheid is dat al hierdie instrumente jare sal neem om resultate op te lewer, aangesien goeie beleidsvoornemens nie maklik hul weg na die praktyk vind nie. ${ }^{62}$

\subsubsection{Waterverbruik en verdampingspatrone van die swartwattel}

Voordat gekyk word na die betekenis van die WVW-program is dit noodsaaklik om aandag te gee aan die watergebruik van die swartwattel. Tans is die presiese waterverbruik van uitheemse indringerplante in Suid-Afrika steeds grootliks onbekend. Dit voeg verdere onsekerheid by die onduidelikheid wat alreeds bestaan met betrekking tot die uitwerking wat die verwydering van hierdie bome op stroomvloei het. ${ }^{63}$ In verskeie studies wat op verskillende plekke in Suid-Afrika onderneem is, is die watergebruik van wattels ondersoek deur gebruik te maak van die daaglikse sapvloei wat vir elke proefboom aangeteken is. Dit is dan vermenigvuldig met die aantal bome van dieselfde grootteklas op 'n afgebakende terrein om die sapvloei van die hele terrein te bepaal. Hierdie model word as nuttig beskou vir die voorspelling van die daaglikse waterverbruik van digte stande swartwattels in toestande waar die bome geen waterstres in enige seisoen van die jaar ondervind nie $^{64}$ (byvoorbeeld in oewersones). Die waterverbruik en verdampingspatrone kan ook afgelei word deur die ouderdom-biomassa-stroomvloeireduksiekurwes toe te pas. Deur die toepassing hiervan staan die watervoordeel nou, ná die skoonmaakproses van wattels, na raming tussen 50 en 130 miljoen kubieke meter jaarliks. ${ }^{65}$

\subsubsection{Die Werk-vir-Water-program}

Om die probleem van uitheemse indringerplante, hoofsaaklik swartwattel, die hoof te bied, het die regering onder meer die WVW-program begin. Die program, wat deel uitmaak van die Heropbou- en Ontwikkelingsprogram (HOP), ${ }^{66}$ is in 1995 deur die Suid-Afrikaanse regering geloods as 'n multidepartementele program van openbare werke om die probleem van uitheemse indringerplante aan te pak en om werkloosheid onder die minder geskoolde mense van die gemeenskap - hoofsaaklik landelike vroue, jong mense en gestremdes - te verminder. Die werk van hierdie mense is daarop gerig om watersekuriteit, ekologiese integriteit of ongeskondenheid te verhoog, die produktiewe potensiaal van die grond te herstel en volhoubare gebruik van natuurlike hulpbronne te bevorder. ${ }^{67}$ Op grond van die Departement Waterwese en Bosbou se ondervinding oor baie jare met betrekking tot die uitroeiing van uitheemse indringerplante het 
die Hoofdirektoraat van Bosbou uitgebreid betrokke geraak by die beplanning en uitvoering van die HOP se Nasionale Waterbewaringsprogram. ${ }^{68}$ Die WVW-program is aktief in baie streke in Suid-Afrika en word befonds deur groot bydraes van sowel die regering as die privaat sektor. ${ }^{69}$ Die program is gemik op die verwydering van alle indringerplante van die oewers van waterstrome met die doel om die watervloei te verbeter. ${ }^{70}$ Daar word geglo dat stroomvloei sal versterk namate digte stande indringerbome deur inheemse kruidagtige of struikgewasse vervang word. $^{71}$

Die swartwattel het ambivalente betekenis in die lewe van landelike mense. Dit is 'n hulpbron met veelvuldige gebruike en 'n voorsiener van brandstof aan duisende arm landelike huishoudings, maar soos reeds gesê, is dit ook ' $n$ uitheemse indringerplant wat grond inneem en reuse-hoeveelhede water uit die grond opsuig en strome verstop. Namate indringerspesies meer grond inneem en so bydra tot die verswakking van die natuurlike hulpbronne, raak die behoefte aan aktiewe grondbestuur al hoe dringender. Skadelike uitheemse indringerplante bedreig menslike gemeenskappe en natuurlike ekosisteme oor die hele wêreld en veroorsaak 'n toename in landbou-onkruid en insekplae. Hierdie plante moet uitgeroei word aangesien hulle die stabiliteit van die ekosisteem kompromitteer en 'n bedreiging vir ekonomiese produktiwiteit is. ${ }^{72}$

\subsubsection{Voordele van die Werk-vir-Water-program}

Die WVW-program was van die begin af 'n sukses. Sedert die instelling van die program het daar baie voordele vir sowel die regering as die algemene publiek gespruit.

- Sedert Oktober 1996 is sowat 66000 nuwe werkgeleenthede in Suid-Afrika geskep.

- Daar word geraam dat die verwydering van indringerplante die watervloei van sommige riviere tot $120 \%$ sal laat toeneem en ook sal lei tot meer produktiewe vleilande, estuariums en watertafels.

- Die sukses van die program kan afgelei word daarvan dat daar binne die eerste ses maande indringerplante van 5000 hektaar grond in Mpumalanga verwyder is.

- Dit het ook gelei tot die rehabilitering van verswakte grond, met 'n sterk klem op grondsorg deur die Departement Landbou en Grondsake om die volhoubare produktiwiteit van die grond te verseker.

- Verder is die pogings versterk deur biodiversiteit en die ongeskondenheid van stroomgebiede te bewaar,

- Daar was 'n afname in die voorkoms en intensiteit van brande.

- Die ontwikkeling van sekondêre nywerhede wat op die verwyderde hout gebaseer is.

- Die bemagtiging van mense deur middel van 'n arbeidsintensiewe benadering tot die werk. Dit het gelei tot werksgeleenthede in die WVW-program vir meer as 42000 mense teen die einde van die 1998/9 finansiële jaar.

- Sedert 1995 tot 1998/9 is 169114 hektaar grond skoongemaak en word beoog om 'n verdere 184302 hektaar skoon te maak in die voortsetting van die program. Rehabilitasiewerk is op 7955 hektaar gedoen. Teen die einde van 2003 is byna 1,2 miljoen hektaar uitheemse indringerplante van wisselende digtheid uitgeroei.

- Dit is 'n belangrike stap in die rigting van die bestuur en beheer van uitheemse indringerplante wat steeds teen 'n kommerwekkende tempo versprei. Waardevolle lesse is geleer in die benadering tot sowel uitroeiing as heraanplanting. Een hiervan was die besondere herstelvermoë van die natuurlike plantegroei, veral in vleilandgebiede wat 30 tot 40 jaar lank deur uitheemse indringerplante gekoloniseer was. Vleilandplantegroei het te voorskyn gekom sodra die watervlakke gestyg het en die vleie weer herstel het. Aan die ander kant was daar gebiede waarin die vernietigende invloed van die langtermynverdringing geblyk het uit die stadige herstel van die natuurlike plantegroei, wat aangehelp moes word deur die heraanplanting van inheemse plante. ${ }^{73}$ 
- Die skoonmaak van stroomgebiede waar daar digte indringing was, het ook daartoe bygedra dat groot kapitale investering in skemas om waterbronne te vergroot, nou met etlike jare uitgestel kan word. Dit het ook die potensiaal om die wateropbrengs van reservoirs te verhoog teen ' $\mathrm{n}$ mededingende of laer koste-eenheid in vergelyking met konvensionele uitbreidingskemas wat gebaseer is op die opdamming of herleiding van water. ${ }^{74}$

- In KwaZulu-Natal het die verwydering van swartwattels van die walle van die waterlope gelei tot die verbetering van die watervloei in die Bulwerdam, wat in die sewe jaar voordat dit in September 1996 oorgeloop het, nooit vol was nie.

- Swartwattels moet meganies uit die waterlope verwyder word. Aangesien brand saadgroei stimuleer, kan hierdie bome nie gebrand word om die uitroeiing te vergemaklik nie. Waar hierdie bome verwyder word, word gras geplant om gronderosie te bekamp. Tot September 1996 is 3000 hektaar grond in KwaZulu-Natal herwin deur die uitroeiing van indringerplante. $^{75}$

Ná 'n uitgebreide navorsingsprogram is tot die gevolgtrekking gekom dat indien swartwattels van die oewers van strome verwyder word en deur inheemse kruidagtige plante vervang word, dit inderdaad kan lei tot 'n aansienlike verlaging in jaarlikse verdampingstranspirasie (VT). Op sy beurt kan dit weer lei tot die versterking van stroomvloei. Hoewel dit 'n positiewe aspek is, het die studie ook duidelik getoon dat die jaarlikse VT aansienlik wissel in verskillende oewerplantgemeenskappe. Dit impliseer dat die strukturele en fisiologiese kenmerke van sowel die voor-uitroeiings- as die na-uitroeiingsplantegroei in ag geneem moet word ten einde die netto verandering in VT te kan voorspel. Hierdie gevolgtrekking stem ooreen met vroeëre navorsing wat daarop gedui het dat 'n verbeterde metodologie van algemene toepasbaarheid nodig is om die akkuraatheid van waterverbruikvoorspellings vir 'n wye reeks uitheemse en inheemse plantgemeenskappe te verhoog. Hierdie voorspellings is van die uiterste belang om skoonmakoperasies in areas wat deur uitheemse bome ingeneem is, te kan prioritiseer. ${ }^{76}$

\subsubsection{Die koste van die Werk-vir-Water-program}

Die regering as die hoofborg van die WVW-program het aansienlike fondse beskikbaar gestel deur middel van die Departement Waterwese en Bosbou (DWB). Dit is aangevul deur verdere ruim befondsing uit die departement se toewysing vir armoedeverligting. ${ }^{77} \mathrm{Om}$ dit in perspektief te plaas: die begroting is vermeerder van R25 miljoen in die 1995/1996 finansiële jaar tot meer as R400 miljoen in die 2002/2003 finansiële jaar. Teen die einde van die 2002/2003 finansiële jaar is sowat R1,59 miljard in totaal bestee aan die uitroeiprogram (dit wil sê in die eerste sewe jaar van die program se bestaan). In dié proses is infestasies op 1,2 miljoen hektaar uitgeroei. Dit is $12 \%$ van die geraamde 10,5 miljoen hektaar infestasies in die land. Hierdie syfer is ietwat misleidend, aangesien dit ' $n$ wye verskeidenheid digthede dek. ${ }^{78}$ As hierdie feit in ag geneem word, is dit beter om te verwys na die volumes hout wat verkry is eerder as na die aantal hektaar wat skoongemaak is.

\subsubsection{Kritiek op die Werk-vir-Water-program}

Die WVW-program was nie net 'n finansiële las vir die belastingbetaler nie, maar kan ook op ander gronde gekritiseer word:

- Die WVW-program as deel van die Nasionale Waterbewaringsveldtog is 'n voorbeeld van ' $n$ regeringsinisiatief wat as konsep baie edel is, maar baie moeilik is om te implementeer in areas wat in gemeenskapsbesit is (juis die gebiede waar werkloosheid 'n groot probleem is). Die rede hiervoor is die burokratiese parameters en die spanninge wat daar bestaan met betrekking tot toegang tot plaaslike hulpbronne en eienaarsregte. Raadplegende prosesse in 
twee Gemeenskapsgebaseerde Grondbestuur- (GGGB) loodsareas het getoon dat die inwoners die WVW-program as 'n belangrike maar problematiese bydraer tot landelike lewensonderhoud sien in die lig van die program se benadering waarin daar teen 'n vinnige pas weggespring word en net so vinnig weer gehalt word. Daar is aanvanklik pieke van geldinvloei na die gebied, maar wanneer 'n fase van die projek afgehandel is, verdwyn die werksgeleenthede weer. Die WVW-program volg 'n "kitsoplossing"-benadering tot wattelbestuur. Wat kortkom, is 'n langtermynprogram van volhoubare bestuur. ${ }^{79}$

- Dit is moontlik dat begrotings in die toekoms nie toegeken sal word vir die voorsetting van die program nie. Dit maak dit noodsaaklik dat daar in die toekoms ander aansporingsmiddels as lone sal moet wees om landelike mense aan te moedig om die swartwattelprobleem te beheer. Die grond wat skoongemaak is, kan vir meer produktiewe doeleindes gebruik word, gepaard met 'n meer betroubare watervoorsiening. Waar die voorsiening die potensiaal vir plaaslike gebruik oorskry, moet oorweging geskenk word aan mikroprosesserings-"industrieë" en skakeling met eksterne markte. In die twee loodsareas is voorgestel dat die gekontrakteerde skoonmaak- en opvolgspanne 'n persentasie van hul inkomste bydra tot 'n ontwikkelingsforum om die koste te dra van nie-WVWprosesseringspanne wat onder andere vuurmaakhout kloof en in sakke verpak, spanhoute bondel, en houtskool en meubels produseer om plaaslik te verkoop. ${ }^{80}$

- Die mees onmiddellike gevaar vir die sukses van die WVW-program as 'n omgewingsrehabilitasieprogram is dat die wil by regerings- en ander befondsingsinstansies asook grondeienaars sal ontbreek om die opvolgprogram aan die gang te hou. Aangesien dit arbeidsintensief is, is dit ' $n$ duur program. Dit is ook ' $n$ program wat oor ' $n$ baie lang termyn sal moet strek en wat moontlik 'n langer lewensduur sal hê as die leeftyd van die inisieerders daarvan. Die rede hiervoor is dat 'n uitheemse indringerplant 'n groot saadbedding het wat baie lank kan bly leef. Opslag kan skrikwekkende afmetings aanneem indien dit nie gereeld (op 'n jaarlikse grondslag) uitgeroei word nie. Die grondrehabilitasieen erosiebeheerprojekte, veral in vleilandgebiede, is ' $n$ waardevolle aspek van die WVWprogram wat baie voordeel inhou met betrekking tot watersekuriteit en die vermindering van vloedskade in oewergebiede. ${ }^{81}$

- Verdere kritiek teen die WVW-program is die manier waarop die bome afgekap word. Dit is belangrik om daarop te let dat bome wat bo die grond afgekap word en nie behandel word nie (byvoorbeeld met onkruiddoder), sal uitloop (soos in die geval van die groenwattel), wat tot nog erger vervuiling sal lei. Stamme wat bo die grond afgekap is, moet dus met 'n oplossing behandel word. Die kerf van 'n ring in die bas is ook 'n suksesvolle manier waarop groot bome doodgemaak kan word. Chemiese behandeling asook biologiese behandeling kan hier toegepas word. ${ }^{82}$

- Kommer is ook uitgespreek dat daar nie effektiewe metodes ontwikkel word vir die herstel van ekosisteme nie - een van die baie wetenskaplike uitdagings waarmee die program te kampe het. ${ }^{83}$

- Die digste stande indringerbome kom dikwels voor in oewergebiede, en daar word geglo dat boomuitroeiing naby die waterstrome die stroomvloei aansienlik sal verbeter. ${ }^{84}$ Hierdie stroomvloeitoenames gee dikwels nie ' $n$ akkurate beeld van die hidrologiese veranderinge oor die langer termyn nie. Sulke metings neem nie die koers van totale verdamping in ag by die plantegroei wat hulself uiteindelik in die skoongemaakte gebiede hervestig nie. ${ }^{85} \mathrm{Na}$ raming gebruik uitheemse indringerplante 3300 miljoen kubieke meter water jaarliks. Hierdie syfer is bereken deur gebruik te maak van die ouderdom-biomassa-stroomvloeireduksiemodel. In die Konsepstrategie vir Nasionale Waterhulpbronne (Konsepstrategie) word die waterverbruik geraam op 14000 kubieke meter water jaarliks. Hierdie verskil kan waarskynlik toegeskryf word aan 'n onderskatting in die Konsepstrategie van die water wat deur uitheemse indringerplante gebruik word. ${ }^{86}$ 
Daar behoort kennis geneem te word van die resultate van 'n aantal navorsingsprojekte in stroomgebiede wat konsekwent aangetoon het dat bosaanplanting stroomvloei aansienlik sal laat afneem waar die plantegroei voor die bosaanplanting bestaan het uit seisoenaal dormante berggrasveld of fynbos. Dit is ook belangrik om daarop te let dat die netto-verskil in VT tussen ruigtes uitheemse bome en fynbos in oewergebiede taamlik kan verskil van dié in ander gebiede omdat grondwater die hele jaar lank beskikbaar is en omdat plante sterker groei in oewergebiede. Nog 'n aspek wat in gedagte gehou moet word, is dat die watergebruik van uitheemse indringerbome in Suid-Afrika - soos reeds voorheen vermeld - grootliks onbekend is, wat nog verder bydra tot onsekerheid oor die effek van indringer-uitroeiing en die invloed daarvan op stroomvloei. Aan die ander kant het eksperimente getoon dat daar 'n verbetering in watervloei is ná die uitroeiing van indringerbome in oewergebiede, maar dit bring nie, soos reeds gestel, die water in berekening wat gebruik word deur die inheemse plantgemeenskap wat met verloop van tyd op die terrein ontwikkel nie. ${ }^{87}$ Indien die inheemse plante wat vestig egter pioniers van die plantgemeenskap is en die ekosisteem hervestig, dan behoort die waterverbruik optimaal vir die ekosisteem te wees. Die prestasies van die WVW-program was beduidend in die lig daarvan dat daar vir baie jare nie 'n bemagtigende regs- en institusionele omgewing was vir die bestuur van uitheemse indringerspesies nie. Die program se uitgangspunt is vanuit ' $\mathrm{n}$ ekologiese, sosiale en ekonomiese perspektief as gesond beskou. Die mening bestaan dat verhoogde aanspreeklikheid, gebaseer op die opheldering van 'n mandaat, effektiewe vennootskappe met die regering en meer effektiewe institusionele reëlings, dringende vereistes is. Die manier waarop hierdie kwessies hanteer word, sal van deurslaggewende belang wees ten einde te kan voortbou op aanvanklike suksesse. ${ }^{88}$ Hoewel die WVW-program nie sonder probleme is nie, kan dit beskou word as een van die suksesvolste geïntegreerde omgewings- en sosiale rehabilitasieprogramme wat die regering nog onderneem het.

\subsubsection{Die Werk-vir-Water-program en menslike ontwikkeling}

Menslike ontwikkeling het ook gebaat by die WVW-program. Dit het die ideale geleentheid gebied om mense op te lei in 'n reeks werkverwante en algemene lewensvaardighede. Opleiding is 'n kritieke komponent van die program en dit dra by tot die menswaardigheid van die betrokkenes wat beleef dat hulle waardevolle werk doen, en boonop opleiding kry wat hulle 'n groter kans op werksgeleenthede in die toekoms gee. In die 1998/99 finansiële jaar is 'n totaal van 70500 persoonsdae aan opleiding gewy. In een stadium het die WVW-program se arbeidsmag uit $56 \%$ vroue bestaan. Die bemagtiging van vroue is hoog op die WVW-program se lys van doelwitte. ${ }^{89}$ In hierdie proses is meer as 20000 mense wat voorheen werkloos was hoofsaaklik vroue - opgelei en in diens geneem. Hierdie reuse-rehabilitasieprogram vir stroomgebiede het in een stadium 303 uitroeiterreine en 43 vleiland-rehabilitasieprojekte regdeur Suid-Afrika ingesluit. Die WVW-program het reeds erkenning gekry as 'n wêreldleier op hierdie gebied, en het tot in Januarie/Februarie 2004 altesaam 33 nasionale en internasionale toekennings ingeoes. Terselfdertyd is 15 miljoen persoonsdae diens gegenereer. ${ }^{90}$ Die uiteindelike doelwit is om 'n situasie te bereik waar die bemagtigde werkers lewensvatbare sakeeenhede kan vorm wat kan tender vir werk wat voortspruit uit die WVW-program. Dit behoort ook daartoe te lei dat sulke mense in staat is om vir ander werk buite die WVW-program te tender deurdat hulle generiese bestuurs- en entrepreneursvaardighede ontwikkel het. Dit behoort 'n vlak van volhoubaarheid binne die WVW-program te skep wanneer die eksterne bronne van befondsing uitgeput is. ${ }^{91}$

Verbeterde biodiversiteit was nie die enigste sukses wat met die WVW-program behaal is nie; dit het ook bykomende inkomstemoontlikhede geskep. Die span by Graskop in Mpumalanga verkoop byvoorbeeld die houtvesel wat hulle afkap as brandhout, houtskool word geproduseer, planke word met 'n mobiele saag gesaag en houtspaanders word aan 'n fabriek in Richardsbaai gelewer vir die vervaardiging van houtpulp. Die veiligheid van die gesinne van die 
werkers word ook in ag geneem. Bewaarskole is gestig as plekke van veiligheid vir die kinders van die werkers en opleidingsprogramme is ingestel vir die opheffing van die plaaslike gemeenskappe. ${ }^{92}$

Daar is ook 'n ander vlak waarop die WVW-program 'n positiewe uitwerking het: dit lewer 'n belangrike bydrae tot die oorkoming van ou rasseskeidings in die land deurdat daar aktief gepoog word om veelrassige spanne op te bou om 'n baie aktuele probleem die hoof te bied. Die algehele relevansie van hierdie komponent kan opgesom word deur te verwys na die bydrae wat dit lewer tot die regering se Masakhane-veldtog. Die gemeenskappe waaruit werkers getrek word, word bemagtig om vir dienste te kan betaal en om beter te verstaan watter voordele dit inhou om te kan werk vir die verbetering van die omgewing. Dit is ook 'n voorbeeld van hoe vennootskappe op interdepartementele vlak in die regering geskep kan word. Die sukses van die WVW-program blyk daaruit dat 313 inisiatiewe in die 2000/1 finansiële jaar onderneem is. Die program het in daardie tydperk 22718 mense in diens gehad, insluitende die bestuur. Altesaam 17266 van hierdie mense is vergoed met fondse afkomstig uit die Fonds vir Armoedeverligting. ${ }^{93}$

\subsubsection{Biologiese beheer}

Die instelling van die WFW-program het bygedra tot die versterking van die beheer van uitheemse indringerplante in Suid-Afrika. Biologiese beheer is 'n praktyk waarin gasheerspesifieke plantvretende insekte, myte en patogene, ook bekend as biologiese beheeragente, wat die indringerplante se natuurlike vyande uitmaak, van hul lande van oorsprong ingebring word en in die nuwe land waar die plante 'n probleem geword het, vrygestel word. Die invoering van hierdie agente bedreig nie die inheemse plante nie aangesien hulle net op die teikenonkruid kan oorleef. Hulle sterf uit as daar nie meer van hul gasheerplante beskikbaar is nie. Hierdie metode is kosteeffektief en veilig in vergelyking met plantdoders en meganiese prosesse. Dit is ook ' $\mathrm{n}$ selfonderhoudende proses. Van die voordele wat dit inhou is onder meer volhoubare befondsing, fondse vir navorsing oor onkruid, 'n behoorlike implementeringsprogram met versterkte biologiese beheer, verbeterde internasionale samewerking en die samestelling van spanne interdissiplinêre navorsers wat entomoloë, plantpatoloë en plantekoloë insluit. ${ }^{94}$ Een van die agente wat in SuidAfrika vrygestel is om die verspreiding van die swartwattel teen te werk is Melanterius maculatus [outeur onbekend], 'n saadvretende kalander uit Australië, wat die saadproduksie van die boom beperk. ${ }^{95}$ 'n Fungus wat stompe koloniseer, Cylindrobasidium laeve [outeur onbekend], kan gebruik word om te voorkom dat die stomp weer uitloop nadat die boom afgekap is. Hierdie fungus kom natuurlik voor in Suid-Afrika. Dit koloniseer die hout en groei in die stomp af, en maak dit uiteindelik dood saam met enige lote wat dalk uitgeloop het. Dit is egter ' $n$ arbeidsintensiewe agent, aangesien elke stomp individueel behandel moet word. ${ }^{96}$

\subsubsection{Beperkings op die kweek van uitheemse indringerplante}

Nog 'n metode wat die regering gebruik om uitheemse indringerplante te beperk, te beheer en uit te roei, is om beperkings te plaas op die kweek daarvan, en om grondeienaars verantwoordelik te maak vir die uitroeiing daarvan indien hierdie plante op hul grond voorkom. Dit spreek vanself dat die WVW-program geen nut sal hê indien hierdie plante steeds gekweek word, of op enige grond teenwoordig is, of nie beheer word nie. ${ }^{97}$

\subsection{Navorsing oor uitheemse indringerplante}

Daar word op die volgende gelet: 


\subsubsection{Prominente navorsingsinstellings}

- Die voormalige Stigting vir Navorsingsontwikkeling het omgewingsnavorsing gekoördineer deur middel van nasionale programme vir onder andere ekosisteemnavorsing. Vir hierdie doel is universiteite, verskillende regeringsdepartemente, provinsiale administrasies en privaat instellings wat gemoeid is met omgewingsprobleme, betrek by die nasionale program vir ekosisteemnavorsing. Wat natuurbewaring betref, sluit dit opnames en navorsing in wat verband hou met die status en bewaring van bedreigde habitatte en spesies, asook navorsing oor uitheemse indringerspesies in natuurlike ekosisteme. ${ }^{98}$

- Die Wattelnavorsingsinstituut is in 1946 gestig. ${ }^{99}$ Die regering het finansiële hulp aan die instituut verleen in die vorm van 'n jaarlikse subsidie. ${ }^{100}$ Dit het gebeur ná 'n ooreenkoms tussen die destydse regering en die Suid-Afrikaanse Wattelkwekersvereniging (SAWKV). Die Wattelnavorsingsinstituut staan nou slegs in Engels bekend as die "Institute for Commercial Forestry Research" en is by die Universiteit van KwaZulu-Natal gevestig. ${ }^{101}$

- Voor die stigting van die instituut was die regering betrokke by navorsing oor die sakwurm wat die swartwattels en die wattelbedryf bedreig het. Met behulp van die jaarlikse sakwurmmortaliteitsopname is navorsing gedoen oor die verspreiding van en skade wat deur hierdie insek gedoen is. ${ }^{102}$

- Die wattelbedryf het dus reeds byna sestig jaar lank sy eie navorsingsinstelling. Dit was tot voordeel van die wattelkwekers, aangesien dit aanleiding gegee het tot verbeterde houtteeltegnieke vir die kweek van gewasse en geneties verbeterde plantmateriaal. Hierdie navorsing het groter houtvesel- en basopbrengste asook weerstand teen siektes tot gevolg gehad. Dit het gelei tot groter mededingendheid vir die bedryf as geheel. ${ }^{103}$ Die regering finansier ook navorsing deur die Wetenskaplike en Nywerheidsnavorsingsraad (WNNR), veral in die geval van hierdie artikel die Afdeling Water, Omgewing en Bosboutegnologie. ${ }^{104}$

\subsubsection{Regeringsbefondsing vir navorsing oor uitheemse indringerplante}

Deur middel van die WVW-program het die regering verdere fondse beskikbaar gestel vir navorsing oor uitheemse indringerplante. 'n Bedrag van R42 miljoen is in die tydperk 2001/2003 belê in navorsing om die ontwikkeling en implementering van die program te steun. Dit is omtrent $2,5 \%$ van die jaarlikse programbegroting. Van hierdie totaal was $50 \%$ gerig op biologiese beheer. ${ }^{105}$

\section{SLOTSOM}

Dit is maklik om die swartwattel te veroordeel as 'n uitheemse indringerplant wat die natuurlike habitat, veral die waterstrome, vernietig. Dis 'n groot waterverbruiker en het sedert dit in die land ingebring is groot gebiede ingeneem, waardeur die natuurlike plantegroei in grasvlaktes en fynbos verdring is. Dit skep probleme wat verg dat dit bestry en uitgeroei moet word, wat 'n duur proses en 'n opdraande stryd is. Die boom is 'n kategorie 2 indringer wat, na die uitreiking van 'n permit, slegs in 'n afgebakende area aangeplant mag word. Stappe moet ook geneem word om die verspreiding daarvan te voorkom. Dit is 'n waardevolle houtveselbron vir landelike huishoudings, en het reeds in die verlede 'n grondslag gevorm vir sekondêre ontwikkeling. Die swartwattel is 'n uitstekende brandhout en dit kan in die plek van inheemse houtsoorte vir hierdie doel gebruik word. As 'n hardehoutsoort is dit gebruik vir mynstutte, as bron van tannien vir die leerbedryf, en vir houtvesel vir plaaslike konstruksiewerk en omheining.

Die belang van die boom vir die ekonomie kan nie ontken word nie. Om daardie rede het die regering ingegryp toe daar 'n moontlikheid was dat die bedryf kon ineenstort weens 'n oorproduksie van wattelbas. In die verlede was dit 'n bedryf wat werkgeleenthede geskep het, 
veral vir die agtergestelde lede van die gemeenskap, en in die toekoms sal dit steeds die geval wees. Baie jare lank het tallose individue, van die boer wat die bome gekweek het tot die laags besoldigde werker in die prosesseeraanlegte, lewensonderhoud daaruit geput. Hierdie mense sal nooit die boom as 'n vloek beskou nie. Afgesien daarvan het die bedryf ook aansienlike bedrae aan buitelandse valuta vir die land verdien deur wattelbas en wattelprodukte uit te voer. Die bedryf het ook waarde tot sy produkte toegevoeg deur nie net die bas nie, maar ook ander produkte soos vernis en kleefstowwe uit te voer. Die wattel is 'n veelsydige boom waarvan ook produkte soos houtspaanders en houtvesel verkry word. As 'n peulgewas plaas die boom stikstof in die grond, waardeur die grond voorberei word vir die volgende boomaanplanting of vir ander gewasse. Diegene wat lewensonderhoud uit die boom verkry, mag dit onder beheer aanplant. In die lig van die sosio-ekonomiese toestande soos werkloosheid in Suid-Afrika, het die regering dan ook vereistes gestel waaraan kwekers en ander grondeienaars moet voldoen. Die probleem lê nie altyd by die boom waar dit behoorlik gekweek word en waar die basiese natuurbewaringsbeginsels toegepas word nie. Die probleem is eerder die individue wat die boom toelaat om buite beheer te raak op hul grond. Die eienaars van kommersiële plantasies het bewys dat die boom ' $n$ bate kan wees. Daar bestaan twyfel of die boom buite die plantasies behoorlik deur die individuele grondeienaars beheer kan word, sodat dit waarskynlik 'n indringerplant sal bly met al die negatiwiteit wat daaraan gekoppel word.

Een van die belangrikste redes waarom indringerplante ' $n$ probleem is, is dat hulle baie water gebruik en inheemse plante verdring, wat lei tot die uitsterwing van diere wat afhanklik is van dié plante. Aangesien hulle in digter stande groei as natuurlike plante, veroorsaak hulle verwoestende brande. Individue kan hierdie probleem help oplos deur uitheemse indringerplante uit te kap, deur hul bure te oorreed om dit ook te doen, en deur slegs inheemse plante op hul eiendom te plant.

Die uitroei van uitheemse indringerplante in verskillende dele van die land sal lei tot verskillende stroomgebiedresponse. Daar sal plaaslike evaluerings van sulke response gedoen moet word vir die prioritisering van die skoonmakproses en om 'n koste-voordeel-ontleding van die proses te kan maak. Evaluering van die effektiwiteit, doeltreffendheid en ekonomiese haalbaarheid van die proses sal 'n aanduiding gee van die sukses van die regering se beleid van betrokkenheid by die swartwattelbedryf. Wat die WVW-program betref: dit is effektief in die sin dat dit 'n werkskepper is, dat dit lei tot die verryking van die biodiversiteit, en dat indringerbome oor groot oppervlakke uitgeroei word. Dit is egter moeilik om hierdie waardes in geld om te sit. Om egter net die area wat skoongemaak is in ag te neem, sal nie ' $n$ ware beeld van die situasie gee nie, aangesien die digtheid van die bome wat verwyder is of die volume van die hout wat geoes is nie in berekening gebring word nie. Die projek gaan om werkverskaffing, die opheffing van vorige benadeelde gemeenskappe en die kweek van 'n kultuur om die omgewing te bewaar. Wat die bekostigbaarheid van die program betref, is die vraag nie of die land die projek finansieel kan bekostig nie, maar of daar enige ander manier is waarop die probleem hanteer kan word. Die gevolge is afgryslik indien die land nie die stappe neem nie.

Om die aanvanklike vraag, naamlik of die swartwattel 'n seën of 'n vloek vir SuidAfrika is, te beantwoord, moet daar op die volgende gelet word:

- Riglyne is vir die individu daargestel om die swartwattel volhoubaar te bestuur.

- Realistiese beheer, soos deur wetgewing aangedui, moet toegepas word aangesien SuidAfrika nie oor die nodige inheemse bome vir ekonomiese gebruik beskik nie.

- As daar op die verspreiding van die boom buite die kommersiële plantasies gelet word, kan die afleiding gemaak word dat talle individue hulle nie juis steur aan die riglyne om die verspreiding van die boom te voorkom nie.

- Word daar egter gekyk na die feite wat deur die navorsing aan die lig gebring is, kan die swartwattel net as 'n vloek beskou word. Dit sou vir die ekologie en die meeste van die inwoners baie beter gewees het indien die boom nooit die land binnegebring is 


\section{VERKORTE CURRICULUM VITAE}

Frank Henry Smith begin sy loopbaan op 19 Januarie 1962 by die destydse Suid-Afrikaanse Polisie te Germiston. Hy dien agtereenvolgens te Germiston, Suid-Afrikaanse Polisie-kollege te Pretoria, Johannesburg, Roodepoort, Evatt in Suid-Natal, Tsolo, Trompsburg en die Suid-Afrikaanse Polisiehoofkantoor Pretoria. Op 1 Maart 1978 verlaat hy die diens van die Suid-Afrikaanse Polisie as luitenant en sluit an by die personeel van die Suid-Afrikaanse Reserwebank. Op 1 Augustus 1983 aanvaar hy 'n pos by die voormalige Technikon Suider-Afrika as lektor in die Departement Staatsadministrasie en vorder mettertyd tot departementshoof in die Departement van Polisie-administrasie. Gedurende die tydperk gee hy ook as deeltydse lektor onderrig by die voormalige Technikon Witwatersrand. Op 1 Januarie 1989 tree hy in diens van sy huidige werkgewer, die Universiteit van Suid-Afrika, as lektor by die Departement van Publieke Administrasie en Bestuur. Op 1 Januarie 1994 word hy bevorder tot senior lektor in dieselfde Departement en op 1 Julie 2005 tot medeprofessor. Hy begin sy akademiese studies as afstandsonderrig student gedurende 1972 by die voormalige Pretoriase Kollege vir Gevorderde Tegniese Onderwys en verwerf aan die einde van 1974 die Nasionale Diploma in Staatsadministrasie. Gedurende Januarie 1976 skryf hy as student in vir die BA-graad by die Universiteit van Suid-Afrika en behaal die graad aan die einde van 1979 met hoofvakke Publieke Administrasie en Staatsleer. Hierna volg 'n BA-Honneursgraad (Publieke Administrasie) in 1981, 'n MA-graad in 1988 en 'n D.Litt. et Phil-graad gedurende 1993. Hy is op 7 Oktober 1967 getroud met Hettie Fourie en die egpaar het twee dogters. Die gesin woon sedert 1979 in Centurion.

\section{BIBLIOGRAFIE}

1. Fernkloof Nature Reserve. (2004). - Alien vegetation. http:/fernkloof.com/alien.my [1 March 2004].

2. Cape Colony. 1882. Forestry Annual Report (Cape Town, Government Printer) p. 15-25.

3. Cape Colony. 1879. Forestry Annual Report (Cape Town, Government Printer) p. 2-3.

4. Mentioned in 1 above

5. Suid-Afrika. 1989. Departement van Omgewingsake. Wet op die Wattelbasnywerheid, 1960, wysiging van regulasies, goewermentskennisgewing no. R.2505, Staatskoerant vol. 293, no. 12181, 17 November, p. 8.

6. Black Wattle. 2004. Conservation Technical Services cc. Http://home.mweb.co.za/contec/wattle.htm [1 March 2004].

7. Henderson, L. 2001. Alien weeds and invasive plants: a complete guide to declared weeds and invaders in South Africa, including another 36 species invasive in that region. (Pretoria: Plant Protection Research Institute, Agricultural Research Council) p. 220.

8. National Archives of South Africa, box file, TAD 1004 (2498), file N.750/2, letter F/A 7930 dated 1912-01-26 from the Chief Conservator of Forests to the Secretary of Agriculture.

9. National Archives of South Africa, box file TAD 437, file G2030/04-G2080/04, letter G2030 dated 1904-11-03 from the Transvaal Colonial Director of Agriculture to the Inspector of Schools, Pretoria District.

10. National Archives of South Africa, box file LDE-N (Lands Natal), volume 407, file 4059, letter S.G. 372-10 dated 1910-08-01 from the Natal Colonial Secretary of the Land Board to FR Brickhill.

11. Black Wattle. 2004. Conservation Technical Services cc. http://home.mweb.co.za/co/contec/wattle.htm [1 March 2004].

12. Forestry SA - Industry Papers. The Wattle Industry: Forestry South Africa. http://www.forestry.co.za/forestry.nsf/Content/The Wattle Industry.html [4 February 2004].

13. National Archives of South Africa, box file CEN, volume 1092, file SF 160/2, letter by D. Webb dated 1944-05-17 to the Chief: Division Entomology.

14. National Archives of South Africa, box file CEN, volume 1092, file SF 160/2, letter by the Entomologist, College of Agriculture, Cedara, dated 1944-05-02 to the Chief Entomologist. 
15. South Africa. 1976. Department of Information. The Republic of Transkei (Pretoria, Chris van Rensburg Publishers), p. 147-148.

16. Keyter, E. (ed.). 1990. Official Yearbook of the Republic of South Africa, 1989-90 (Pretoria, Government Printer), p. 373.

17. Transvaal. 1876. Transvaalse Goewerments kennisgewing 2 van 5 Januari 1876, Staats Courant der Zuid-Afrikaanche Republiek, no. 614, vol. XVIII.

18. South Africa. 1989. Department of Environment Affairs. Strategic Forestry Development Plan for South Africa. (Pretoria: Department of Environment Affairs) p. 10.

19. Forestry SA - Industry Papers. The Wattle Industry: Forestry South Africa. http://www.forestry.co.za/forestry.nsf/Content/The Wattle Industry Industry.html [4 February 2004].

20. Keyter, E. (ed.). 1990. Official Yearbook of the Republic of South Africa, 1989-90 (Pretoria, Government Printer), p. 373.

21. Black Wattle. Conservation Technical Services $c c$. http://home.mweb.co.za/contec/wattle.htm [1 March 2004].

22. Black Wattle. 2004. Conservation Technical Services cc. Http://home.mweb.co.za/contec/wattle.htm [1 March 2004].

23. Forestry SA - Industry Papers. 2004. The Wattle Industry: Forestry South Africa. Http://www.forestry.co.za/forestry.nsf/Content/The Wattle Industry Industry.html [4 February 2004].

24. History and Information. http://www.mimosa-sa.com/history.htm [30 April 2004].

25. History and Information. http://www.mimosa-sa.com/history.htm [30 April 2004].

26. Cape Colony. 1880. Ministerial Department of Crown Lands and Public Works. Report on Crown Forests and Plantations of the Colony for the year 1879 (Cape Town, Government Printer) p.12.

27. Cape Colony. 1876. Ministerial Department of Crown Lands and Public Works. Report of Knysna Forest, King William's Town, Alexandra, Victoria East, Stockenstroom, Bathurst and Drift sands, 1875. (Cape Town, Government Printer) p. 6.

28. Sim, T.R. 1905. Tree planting in Natal. (Pietermaritzburg, Davis and Sons) p. 340 \& 342-346.

29. South Africa. 1976. Department of Information. The Republic of Transkei (Pretoria, Chris van Rensburg Publishers), p. 151.

30. South Africa. 1976. Department of Information. The Republic of Transkei (Pretoria, Chris van Rensburg Publishers), p. 151.

31. Grondwet van die Republiek van Suid-Afrika 110 van 1983, aanhef.

32. Keyter, E. (ed.). 1990. Official Yearbook of the Republic of South Africa, 1989-90 (Pretoria, Government Printer), p. 373-374.

33. National Archives of South Africa, box file TES 33/740-33/749 (5787), file 33/740, letter C.304/1 dated 1958-10-17.

34. Wet op die Wattelbasnywerheid 23 van 1960.

35. Suid-Afrika. Volksraad. Debatte. 1960. Derde sessie, twaalfde Parlement, 15 Januarie tot 04 Maart, (Kaapstad, Staatsdrukker) kolomme 1,289-1,291.

36. Suid-Afrika. Volksraad. Debatte. 1960. Derde sessie, twaalfde Parlement, 15 Januarie tot 04 Maart, (Kaapstad, Staatsdrukker) kolomme 1,289-1,291.

37. National Archives of South Africa, box file LDB, R1178 volume 4, file R1178/1, letter by the SAWGU dated 1962-02-14 to the Department of Agriculture.

38. Wysigingswet op die Wattelbasnywerheid 24 van 1986.

39. Keyter, E. (ed.). 1990. Official Yearbook of the Republic of South Africa, 1989-90 (Pretoria, Government Printer), p. 374.

40. Smith, F.H. 1993. Doelwitbepaling en -verwesenliking in die Suid-Afrikaanse Staatsboswese vanaf 1652 tot 1992. Ongepubliseerde D.Litt et Phil.-proefskrif (Pretoria, Unisa), p. 200.

41. Suid-Afrika. 1984. Departement van Landbou. Verbod op die uitreiking van permitte vir die invoer van sekere beheerde goedere, Goewermentskennisgewing no. R.108, Staatskoerant vol. 223, no. 9047, 27 Januarie, p. 1.

42. Suid-Afrika. 1985. Departement van Landbou. Wet op In- en Uitvoerbeheer, 1963 (Wet 45 van 1963), Goewermentskennisgewing no. R.846, Staatskoerant vol. 238, no. 9693, 12 April, p. 5.

43. Wet op Landbouplae 36 van 1983 subartikel 3(1).

44. Suid-Afrika. 1985. Departement van Omgewingsake, Hoofkantoor, Pretoria omsendskrywe $\mathrm{A} / 10 / 2 / 2 / 8 / 7$ gedateer 1985-07-12. 
45. Suid-Afrika. 1989. Departement van Landbou. Invoer van beheerde goedere sonder permit, Goewermentskennisgewing no. R.1013, Staatskoerant vol. 287, no. 11879, 26 Mei, p. 2 \& 32.

46. Suid-Afrika. 1992. Departement van Waterwese en Bosbou, Hoofkantoor, Pretoria omsendskrywe 10/2/2/1/14 gedateer 1992-11-18.

47. Suid-Afrika. 1989. Departement van Omgewingsake, Hoofkantoor, Pretoria omsendskrywe A/10/2/2/8/1 gedateer 1989-04-28.

48. Suid-Afrika. 1989. Departement van Omgewingsake. Wet op die Wattelbasnywerheid, 1960, wysiging van regulasies, Goewermentskennisgewing no. R.2505, Staatskoerant vol. 293, no. 12181, 17 November, p. 8.

49. Working for Water - Wacking wattles for water - the South African Working for Water Project. 2001. $\mathrm{http}: / / \mathrm{www}$. sciencdeinafrica.co.za/2001/june/wfw/htm [1 March 2004].

50. Zimmerman, H.G., Moran, V.C. \& Hoffman, J.H. 2004. Biological control in the management of invasive alien plants in South Africa, and the role of the Working for Water Programme, S.Afr. Journal of Science, 100(1 \& 2), p.34-40.

51. Allen, R.E. (Ed.). 1992. The Concise Oxford Dictionary of current English. Second reprint. (London: Oxford University Press), p. 1391.

52. Henderson, L. 2001. Alien weeds and invasive plants: a complete guide to declared weeds and invaders in South Africa, including another 36 species invasive in that region. (Pretoria: Plant Protection Research Institute, Agricultural Research Council), p. 9.

53. Henderson, L. 2001. Alien weeds and invasive plants: a complete guide to declared weeds and invaders in South Africa, including another 36 species invasive in that region. (Pretoria: Plant Protection Research Institute, Agricultural Research Council), p. 260-273.

54. Working for Water - Wacking wattles for water - the South African Working for Water Project. 2001. http://www.sciencdeinafrica.co.za/2001/june/wfw/htm [1 March 2004].

55. Hall, J. Environment: alien plant species invade Southern Africa.

http://www.ipsnews.net/africa/print.asp?idnews=19002 [1 March 2004].

56. Working for Water - Wacking wattles for water - the South African Working for Water Project. 2001. http://www.sciencdeinafrica.co.za/2001/june/wfw/htm [1 March 2004].

57. Hall, J. Environment: alien plant species invade Southern Africa. http://www.ipsnews.net/africa/print.asp?idnews=19002 [1 March 2004].

58. Black Wattle. Conservation Technical Services cc. Http://home.mweb.co.za/contec/wattle.htm [1 March 2004].

59. Dye, P., Moses, G., Vilakazi, P., Ndlela, R., \& Royappen, M. 2001. Comparative water use of wattle thickets and indigenous plant communities at riparian sites in the Western Cape and KwaZuluNatal, Water SA, 27(4), October, p. 530.

60. Nel, J.L., Richardson, D.M., Rouget, M, et al. 2004. A proposed classification of alien plant species in South Africa: towards prioritizing species and areas for management action, S.Afr. Journal of Science, January/February, 100 (1 \& 2), p. 56-57.

61. Grondwet van die Republiek van Suid-Afrika Wet 108 van 1996, artikel 24.

62. Wattle. Dealing with wattle sustainability, http://www.eda.org.za/Annreport98/wattle.html [1 March 2004].

63. Dye, P. et al. 2001. Comparative water use of wattle thickets and indigenous plant communities at riparian sites in the Western Cape and KwaZulu-Natal, Water SA, 27(4), October, p. 529.

64. Dye, P. \& Jarmain, C. 2004. Water use by black wattle (Acacia mearnsii): implications for the link between removal of invading trees and catchment stream flow response, S.Afr. Journal of Science, January/February, 100 (1 \& 2), p. 41.

65. Görgens, A.H.M. \& Van Wilgen, B.W. 2004. Invasive alien plants and water resources in South Africa: current understanding, predictive ability and research challenges, S. Afr. Journal of Science, January/February, 100(1\&2), p.32.

66. De Beer, E. 1996. Werk vir water bring nuwe hoop en lewe in verskeie gemeenskappe, Beeld, 3 September, 9.

67. Working for Water - Wacking wattles for water - the South African Working for Water Project. 2001. http://www.sciencdeinafrica.co.za/2001/june/wfw/htm [1 March 2004].

68. South Africa. 1996. Report of the Director-General: Water Affairs and Forestry for the period 1 April 1995 to 31 March 1996, Pretoria, Government Printer. 
69. Dye, P., et al. 2001. Comparative water use of wattle thickets and indigenous plant communities at riparian sites in the Western Cape and KwaZulu-Natal, Water SA, 27(4), October, p. 530.

70. De Beer, E. 1996. Werk vir water bring nuwe hoop en lewe in verskeie gemeenskappe, Beeld, 3 September, 9.

71. Dye, P., et al. 2001. Comparative water use of wattle thickets and indigenous plant communities at riparian sites in the Western Cape and KwaZulu-Natal, Water SA, 27(4), October, p. 529.

72. Richardson, D.M. \& Van Wilgen, B.W. 2004. Invasive alien plants in South Africa: how well do we understand the ecological impacts? S.Afr. Journal of Sciences, January/February, 100 (1 \& 2), p.45.

73. Working for Water - Wacking wattles for water - the South African Working for Water Project. 2001. http://www.sciencdeinafrica.co.za/2001/june/wfw/htm [1 March 2004].

74. Görgens, A.H.M. \& Van Wilgen, B.W. 2004. Invasive alien plants and water resources in South Africa: current understanding, predictive ability and research challenges, S. Afr. Journal of Science, January/February, 100 ( $1 \& 2)$, p.32.

75. Visser, A. 1996. Gulsige bome wat indring, word uitgeroei: HOP -projek help mense, omgewing. Beeld, 3 September, p.9.

76. Dye, P. et al. 2001. Comparative water use of wattle thickets and indigenous plant communities at riparian sites in the Western Cape and KwaZulu-Natal, Water SA, 27(4), October, p. 529.

77. Van Wilgen, B.W. 2004. Scientific challenges in the field of invasive alien plant management, S.Afr. Journal of Sciences, January/February, 100 (1 \& 2), p. 19.

78. Macdonald, I.A.W. 2004. Recent research on alien plant invasions and their management in South Africa: a review of the inaugural research symposium of the Working for Water programme, S.Afr. Journal of Science, January/February, 100 (1 \& 2), p. 22.

79. Wattle. Dealing with wattle sustainability, http://www.eda.org.za/Annreport98/wattle.html [1 March 2004].

80. Wattle. Dealing with wattle sustainability, http://www.eda.org.za/Annreport98/wattle.html [1 March 2004].

81. Working for Water - Wacking wattles for water - the South African Working for Water Project. 2001. http://www.sciencdeinafrica.co.za/2001/june/wfw/htm [1 March 2004].

82. Black Wattle. Conservation Technical Services $c c$. Http://home.mweb.co.za/contec/wattle.htm [1 March 2004].

83. Van Wilgen, B.W. 2004. Scientific challenges in the field of invasive alien plant management, S.Afr. Journal of Sciences, January/February, 100 (1 \& 2), p. 20.

84. Dye, P. et al. 2001. Comparative water use of wattle thickets and indigenous plant communities at riparian sites in the Western Cape and KwaZulu-Natal, Water SA, 27(4), October, p. 529-530.

85. Dye, P. \& Jarmain, C. 2004. Water use by black wattle (Acacia mearnsii): implications for the link between removal of invading trees and catchment stream flow response, S.Afr. Journal of Science, January/February, 100 (1\&2), p. 41.

86. Görgens, A.H.M. \& Van Wilgen, B.W. 2004. Invasive alien plants and water resources in South Africa: current understanding, predictive ability and research challenges, S. Afr. Journal of Science, January/February, 100 ( $1 \& 2)$, p.32.

87. Dye, P. et al. 2001. Comparative water use of wattle thickets and indigenous plant communities at riparian sites in the Western Cape and KwaZulu-Natal, Water SA, 27(4), October, p. 529-530.

88. Van Wilgen, B.W. 2004. Scientific challenges in the field of invasive alien plant management, S.Afr. Journal of Sciences, January/February, 100 (1 \& 2), p. 20.

89. Working for Water - Wacking wattles for water - the South African Working for Water Project. 2001. http://www.sciencdeinafrica.co.za/2001/june/wfw/htm [1 March 2004].

90. Macdonald, I.A.W. 2004. Recent research on alien plant invasions and their management in South Africa: a review of the inaugural research symposium of the Working for Water programme, S.Afr. Journal of Science, January/February, 100 (1\& 2), p. 22.

91. Working for Water - Wacking wattles for water - the South African Working for Water Project. 2001. http://www.sciencdeinafrica.co.za/2001/june/wfw/htm [1 March 2004].

92. De Beer, E. 1996. Werk vir water bring nuwe hoop en lewe in verskeie gemeenskappe, Beeld, 3 September, 9.

93. Working for Water - Wacking wattles for water - the South African Working for Water Project. 2001. http://www.sciencdeinafrica.co.za/2001/june/wfw/htm [1 March 2004]. 
94. Zimmerman, H.G., Moran, V.C. \& Hoffman, J.H. 2004. Biological control in the management of invasive alien plants in South Africa, and the role of the Working for Water Programme, S.Afr. Journal of Science, $100(1 \& 2)$, p.34.

95. Donnely, D. Acacia mearnsii (Black Wattle), http://aliens.csir.co.za/plants/global/continen/africa/safrica/biocontry/fynbos/fabaus/aca [30 April 2004].

96. Wood, A. Acacia mearnsii (Black Wattle), http://aliens.csir.co.za/plants/global/continen/africa/safrica/biocontry/fynbos/fabaus/aca [30 April 2004].

97. Plant invaders 1. Weed warriors. Working for water at South African National Parks. http://www.weedwarriors.co.za/Pests1.html [1 March 2004].

98. Keyter, E. (ed.). 1990. Official Yearbook of the Republic of South Africa, 1989-90 (Pretoria, Government Printer), p. 584.

99. National Archives of South Africa, box file, TES 3/740-33/749 (5787), file 33/740, letter dated 195909-14 from the Secretary of Agricultural Technical Services to the Treasury.

100. National Archives of South Africa, box file, LDB, R.1178 volume 4, file R1178, letter R.34 dated 1946-09-16 from the Director of Forestry to the Secretary of Agriculture.

101. Keyter, E. (ed.). 1990. Official Yearbook of the Republic of South Africa, 1989-90 (Pretoria, Government Printer), p. 373-374.

102. National Archives of South Africa, box file, CEN, volume 1092, reference SF 160/2, letter S.F. 160/2 dated 1944-05-17 from the Chief: Division of Entomology to the Secretary of Agriculture and Forestry.

103. History and Information. http://www.mimosa-sa.com/history.htm [30 April 2004].

104. Baker, G. (Ed.). 2004. S.Afr. Journal of Sciences, January/February, 100 (1 \& 2), p. 01-129.

105. Van Wilgen, B.W. 2004. Scientific challenges in the field of invasive alien plant management, S.Afr. Journal of Sciences, January/February, 100 (1 \& 2), p. 19-20. 